This is an electronic reprint of the original article. This reprint may differ from the original in pagination and typographic detail.

\author{
Author(s): Saarenheimo, Jatta; Aalto, Sanni L.; Syväranta, Jari; Devlin, Shawn; Tiirola, Marja; \\ Jones, Roger
}

Title: $\quad$ Bacterial community response to changes in a tri-trophic cascade during a whole-lake fish manipulation

Year: $\quad 2016$

Version:

Please cite the original version:

Saarenheimo, J., Aalto, S. L., Syväranta, J., Devlin, S., Tiirola, M., \& Jones, R. (2016). Bacterial community response to changes in a tri-trophic cascade during a whole-lake fish manipulation. Ecology, 97(3), 684-693. https://doi.org/10.1890/15-1052.1

All material supplied via JYX is protected by copyright and other intellectual property rights, and duplication or sale of all or part of any of the repository collections is not permitted, except that material may be duplicated by you for your research use or educational purposes in electronic or print form. You must obtain permission for any other use. Electronic or print copies may not be offered, whether for sale or otherwise to anyone who is not an authorised user. 


\title{
Bacterial community response to changes in a tri-trophic cascade during a whole-lake fish manipulation
}

\author{
J. Saarenheimo, ${ }^{1,3}$ S. L. Aalto, ${ }^{1}$ J. Syväranta, ${ }^{1}$ S. P. Devlin,,${ }^{1,2}$ M. Tiirola,,${ }^{1}$ and R. I. Jones ${ }^{1}$ \\ ${ }^{1}$ Department of Biological and Environmental Science, University of Jyväskylä, P.O. Box 35, 40014, Jyväskylä, Finland
}

\begin{abstract}
Microbial communities play a key role in biogeochemical processes by degrading organic material and recycling nutrients, but can also be important food sources for upper trophic levels. Trophic cascades might modify microbial communities either directly via grazing or indirectly by inducing changes in other biotic or in abiotic factors (e.g., nutrients). We studied the effects of a tri-trophic cascade on microbial communities during a whole-lake manipulation in which European perch (Perca fluviatilis) were added to a naturally fishless lake divided experimentally into two basins. We measured environmental parameters (oxygen, temperature, and nutrients) and zooplankton biomass and studied the changes in the bacterial community using next generation sequencing of $16 \mathrm{~S}$ rRNA genes and cell counting. Introduction of fish reduced the biomass of zooplankton, mainly Daphnia, which partly altered the bacterial community composition and affected the bacterial cell abundances. However, the microbial community composition was mainly governed by stratification patterns and associated vertical oxygen concentration. Slowly growing green sulfur bacteria (Chlorobium) dominated the anoxic water layers together with bacteria of the candidate division OD1. We conclude that alterations in trophic interactions can affect microbial abundance, but that abiotic factors seem to be more significant controls of microbial community composition in sheltered boreal lakes.
\end{abstract}

Key words: anaerobic microbes; bacterial community composition; boreal lakes; next generation sequencing; top-down vs. bottom-up control; trophic cascades.

\section{INTRODUCTION}

Microbes have a significant role in biogeochemical cycles in ecosystems, but they also constitute a large fraction of ecosystem biomass and can be an important food source for higher trophic levels, especially in aquatic environments (Tranvik 1992). Thus understanding the abiotic and biotic factors that regulate microbial communities is important. Seasonal succession together with changing temperature and $\mathrm{pH}$ (Lindström et al. 2005, Yannarell and Triplett 2005, Crump et al. 2009, Eiler et al. 2012), light and humic substances (Kent et al. 2004, Haukka et al. 2005), oxygen (Shade et al. 2008, Peura et al. 2012a), and the availability of inorganic and organic nutrients (Zeng et al. 2009, Zhang et al. 2015) are important "bottom-up" factors controlling bacterial community composition. In addition, trophic interactions (i.e., "top-down control") may shape bacterial communities. Previous studies have focused on demonstrating how factors of direct trophic control such as predation (Pernthaler 2005) or resource competition

Manuscript received 10 June 2015; revised 15 September 2015; accepted 17 September 2015. Corresponding Editor: E. van Donk.

${ }^{2}$ Present address: Flathead Lake Biological Station, University of Montana, 32125 Bio Station Lane, Polson, Montana 598606815 , USA

${ }^{3}$ E-mail: jatta.saarenheimo@jyu.fi
(Peura et al. 2012b, de Vries and Shade 2013) have selective community-level effects on bacterial diversity.

Boreal humic lakes receive high organic carbon inputs, especially of dissolved organic carbon (DOC), from forest and peatland catchments. In these environments, microbes have an important role, not only in controlling greenhouse gas fluxes, but in transferring this incoming allochthonous carbon to higher trophic levels via a "microbial link" (Jones 1992, Jansson et al. 2000). Boreal lakes, and particularly smaller ones, exhibit steep vertical gradients of temperature, oxygen, nutrients, and light, meaning that each water layer provides a unique subenvironment for bacteria. Therefore, the composition and function of microbial communities differ markedly between the oxic and anoxic water layers (Shade et al. 2008, Taipale et al. 2009a, Peura et al. 2012a). For example, anaerobic phototrophs, such as green sulfur bacteria (GSB) of the genus Chlorobium, can dominate the anoxic water layers of these lakes (Arvola et al. 1992, Karhunen et al. 2013), whereas methane-oxidizing bacteria (MOB) thrive at the oxic-anoxic interface (Kankaala et al. 2006, Taipale et al. 2009a). The main microbial groups in the oxic upper water layer (epilimnion) have been assigned to Actinobacteria (Lindström and Leskinen 2002, Haukka et al. 2005, Newton et al. 2011) and Betaproteobacteria (Burkert et al. 2003, Grossart et al. 2008). In addition, the suboxic and anoxic lower water layers (meta- and hypolimnion) of these lakes have been 
shown to harbor previously unknown groups, such as candidate division OD1 (Peura et al. 2012a).

As in other ecosystems, the composition and diversity of microbial communities in small boreal lakes are controlled by abiotic bottom-up factors, such as DOC and nutrient concentrations (Peura et al. 2013), and by biotic top-down factors, i.e., grazing (Lindström 2000, Kent et al. 2004). The relative importance of bottom-up and top-down factors varies with respect to the trophic status of the lake, with higher nutrient concentrations increasing bottom-up effects and nutrient-limitation enhancing top-down control (Gasol et al. 2002). In stratified boreal lakes, the oxic epilimnion becomes nutrient-limited during summer, while the anoxic hypolimnion can have high concentrations of phosphate and ammonium, creating different patterns of top-down and bottom-up effects on microbial communities between these depth zones. However, as microbes are an important food source for consumers at higher trophic levels, they can also be controlled indirectly via trophic cascades, whereby predators, by decreasing the abundance of bacterivores, suppress grazing pressure on microbes (Thakur et al. 2014).

Naturally fishless small humic lakes provide excellent environments to study the potential impacts of cascading trophic interactions from higher trophic levels to bacterial communities, as introducing a new top predator is relatively straightforward. Fishless lakes often have dense populations of large zooplankton, such as cladocera from the genus Daphnia. Due to their ability to filter feed on a broad spectrum of particle sizes, Daphnia can exert a significant grazing pressure on all components of microbial food webs, including pico-, nano-, and microplankton (Jürgens et al. 1997, Muylaert et al. 2002). Daphnia can also migrate vertically in the water column, allowing them to utilize resources below the oxic water layers and thereby enabling the use of microbial biomass as energy subsidies when phytoplankton is scarce (Salonen and Lehtovaara 1992). For example, in a small and highly humic Finnish lake Mekkojärvi, Daphnia longispina are known to feed extensively on methanotrophs and partly also on GSB (Taipale et al. 2009b). Altering the food web structure by adding fish as new top predators to this kind of sheltered boreal lake was shown to reduce the zooplankton biomass and alter the zooplankton community structure (Järvinen and Salonen 1998), and can therefore be expected to modify bacterial communities as well.

We experimentally tested the effect of a tri-trophic cascade on microbial communities by dividing a small humic and naturally fishless lake into two basins with a plastic curtain, and adding fish to one basin. Zooplankton biomass decreased rapidly after fish addition to the fishpresent basin, whereas, in the fish-absent basin, the zooplankton biomass increased through the summer toward the autumn (described by Devlin et al. 2015). We studied the changes in environmental parameters and microbial cell numbers, as well as evaluating bacterial community composition using next generation sequencing (NGS) of the 16S rRNA genes. The study covered three open-water seasons and provided a data set with exceptional coverage of temporal and spatial observations of epi-, meta-, and hypolimnetic microbial communities. We expected higher bacterial cell densities after Daphnia removal, taking into account the strong effect of Daphnia on microbes previously observed in this lake (Arvola et al. 1992). A more pronounced effect of Daphnia abundance on the microbial community was expected in the oxic epilimnion where Daphnia mainly feed than in the deeper anoxic hypolimnion, which Daphnia can only visit during short vertical migration forays. In addition, altered trophic cascades were expected to modify microbial community composition via decreased predation pressure, thus favoring fast-growing microbial species.

\section{Methods}

\section{Study lake and design}

Mekkojärvi is a small, shallow (mean depth $3 \mathrm{~m}$ ), and highly humic lake located in southern Finland in the Evo forest area. The lake is steeply stratified and has a shallow ( $\sim .5 \mathrm{~m}$ during the open-water period) oxic epilimnion. The lake is ice covered from November to April and develops total and persistent anoxia during the winter. Mekkojärvi is partially meromictic, as the annual spring mixing can remain incomplete. The lake lacks fish due to the persistent winter under-ice anoxia, leading to exceptionally high summer zooplankton abundance, mainly of Daphnia longispina (further characteristics of Mekkojärvi are given in Salonen and Lehtovaara 1992, and Taipale et al. 2008).

In 2011, 2012, and 2013 Mekkojärvi was divided into two separate basins with a plastic curtain extending from surface to bottom. The curtain was set in place each spring after ice melt and spring mixing. In early July each year, European perch (Perca fluviatilis) were added in numbers representing naturally occurring perch biomass in similar lakes in the Evo forest area (approximately $1 \mathrm{~g}$ fresh mass per $\mathrm{m}^{2}$ of lake surface area). Adult perch $(>12 \mathrm{~cm})$ were added to one basin and juveniles $(<3 \mathrm{~cm})$ to the other basin. However, due to a brief pulse of hypoxic conditions (repeated in every study year) in one basin, the established perch population died shortly after introduction, leaving the basin fishless and thus, in practice, creating two contrasting treatments of fish present and fish absent. Further details of the fish treatments are given in Devlin et al. (2015).

\section{Sample and data collection}

Both basins of the lake were sampled one to two times per month during the ice-free period (see Devlin et al. [2015], for full description of sampling, measurement of environmental factors and nutrients, and of zooplankton identification and calculation). Briefly, on each sampling occasion, temperature and oxygen profiles were measured in situ using a portable field meter (YSI model 58; Yellow Springs Instruments, Yellow Springs, Ohio, USA). Integrated water column samples were collected with a Limnos water sampler (height $60 \mathrm{~cm}$, volume $4.25 \mathrm{~L}$; Limnos, Turku, 
Finland) from epi- $(0-0.5 \mathrm{~m})$, meta- $(0.5-1 \mathrm{~m})$, and hypolimnion (1-3 m), delimited according to thermal and oxygenic stratification. Concentrations of dissolved inorganic $\mathrm{P}\left(\mathrm{PO}_{4}^{3-}\right)$ and $\mathrm{N}\left(\mathrm{NH}_{4}^{+} \mathrm{NO}_{2}^{-}+\mathrm{NO}_{3}^{-}\right)$, and of $\mathrm{DOC}$ in the lake water were determined following standard laboratory methods (available online). ${ }^{4}$ Zooplankton samples were collected with a Limnos water sampler and $6 \mathrm{~L}$ of water were passed through a $50-\mu \mathrm{m}$ mesh net to retain zooplankton. The zooplankton were later identified, counted, and measured under a stereo microscope. Daphnia biomass $(w, \mathrm{mg} \mathrm{C}$ ) was then calculated using length-mass relationships $w=a L b$ from Rahkola et al. (1998) where the intercept $a$ was estimated as 5.66, $L$ is the Daphnia body length in $\mathrm{mm}$, and the slope $b$ was 1.72. Bacterial cell counts were measured from 2012 samples ( $n=42$, covering seven sampling occasions from the three depth layers and both lake basins) by flow cytometry (FACSCanto II; Becton Dickinson Biosciences, Oxford, UK). Water samples $(1.5 \mathrm{~mL})$ were fixed with particle-free $20 \% \mathrm{w} / \mathrm{v}$ paraformaldehyde dissolved in Milli-Q water, $1 \%$ final concentration. The fixed samples were stored at $-20^{\circ} \mathrm{C}$. Before the analyses the samples were thawed and stained with SYBR Green I DNA stain (Sigma-Aldrich) in the 1:5000 final dilution of the initial stock. Yellow-green $0.5-\mathrm{mm}$ beads (Fluoresbrite Microparticles; Polysciences, Warrington, Pennsylvania, USA) were added with known final concentration $\left(10^{5}\right.$ beads $\left./ \mu \mathrm{L}\right)$ to determine absolute cell concentrations (Zubkov and Burkill 2006). Flow cytometry counts were enumerated with Flowing Software (Flowing Software ver 2,5, Turku, Finland).

\section{Bacterial community composition}

Water for DNA extraction was collected from epilimnion $(0-0.5 \mathrm{~m})$, metalimnion $(0.5-1.0 \mathrm{~m})$, and hypolimnion (1.0-3.0 m) and pooled samples from each stratum were stored in 100-mL plastic containers and frozen at $-20^{\circ} \mathrm{C}$. The DNA samples were then freeze dried (Alpha 1-4 LD plus, Christ) and extracted using a PowerSoil DNA extraction kit (MoBio Laboratories) according to the manufacturer's instructions. Altogether, 96 DNA samples were included, covering 16 different sampling time points during the three-year experiment ( $n=4$ in 2011, $n=7$ in 2012, and $n=5$ in 2013) from all three depth layers and from both lake basins. After extraction, DNA concentrations of the samples were measured with a Qubit 2.0 Fluorometer (Invitrogen) using the Qubit dsDNA HS Assay kit (Life Technologies).

Amplification of bacterial 16S rRNA genes (E. coli positions 27 to 338) was conducted using general bacterial primers 27F (5' AGAGTTTGATCMTGGCTCAG 3') and 338R (5'-TGCTGCCTCCCGTAGGAGT-3'). Primer 27F carried an Ion Torrent adaptor $\mathrm{A}$ at the $5^{\prime}$ end and an 11-12 bp barcode followed by a KEY tag, and primer 338R carried a P1 adaptor at the 5' end. PCR amplification for Ion Torrent sequencing was done in $20-\mu \mathrm{L}$ volumes

\footnotetext{
${ }^{4}$ http://www.sfs.fi/
}

containing $1 \mu \mathrm{L}$ of template DNA, $0.5 \mu \mathrm{mol} / \mathrm{L}$ of each primer, $1 \times$ Phusion HotStartII buffer (Finnzymes), $0.02 \mathrm{U}$ Phusion HotStartII polymerase, and $0.3 \mathrm{mmol} / \mathrm{L} \mathrm{dNTPs.}$ Cycling conditions involved an initial denaturing step at $98^{\circ} \mathrm{C}$ for $2 \mathrm{~min}$, followed by 25 cycles of $98^{\circ} \mathrm{C}$ for $10 \mathrm{~s}, 52^{\circ} \mathrm{C}$ for $10 \mathrm{~s}$, and $72^{\circ} \mathrm{C}$ for $30 \mathrm{~s}$, and a final elongation step of $72^{\circ} \mathrm{C}$ for $10 \mathrm{~min}$. The PCR amplicons were purified twice using the Agencourt AMPure XP purification system (Beckman Coulter) and quantified with a Qubit 2.0 Fluorometer. Equal concentrations of bar-coded amplicons were pooled for the emulsion PCR, which was performed using an Ion OneTouch2400templatekit(Life Technologies). Templated beads were purified using the OneTouch ES instrument (Life Technologies) according to the manufacturer's protocol. NGS of the pooled library was conducted starting from the A adaptor using the Ion Torrent Personal Genome Machine (PGM; Life Technologies) with Ion Sequencing $400 \mathrm{kit}$ and Ion 314 Chip. Sequence quality control was done using Mothur (Schloss et al. 2009), whereby sequences shorter than $200 \mathrm{bp}$, low-quality sequences with mismatches in bar code and primer sequences or with homopolymers longer than eight nucleotides, as well as barcodes, primers, and chimeras were removed. A final total of 258572 reads was obtained. The Ion Torrent sequences have been deposited in the NCBI Short read Archive under accession number SRP061976.

To assign reads to operational taxonomic units (OTUs) a 97\% sequence similarity cut-off was used in Mothur (available online)..$^{5}$ OTUs containing at least 50 reads were included in further analysis (covering $79 \%$ of all sequences). A representative sequence from each of the 597 OTUs obtained was classified using the Least Common Ancestor tool of the SINA ALIGNER v1.2.11 (Pruesse et al. 2012). Classification was based on the SILVA taxonomy for the 10 nearest neighbors retrieved from the curated SILVA SSU Ref database Release 106 (Pruesse et al. 2007) with minimal identity of 0.80 . From the 597 OTUs, only seven remained as unclassified at the phylum level.

\section{Statistical analyses}

For studying the bacterial $\alpha$-diversity, the data set was resampled with the command "subsample" in Mothur to gain equal numbers of sequences in each sample (2019 sequences). The $\alpha$-diversity was estimated with the inverse Simpson index as a measure of diversity and with the Chao index as a measure of richness. All statistical analyses were conducted using $\mathrm{R}$ version 3.1.1 (R Core Team 2014). Disparities in $\alpha$-diversity (Chao or inverse Simpson index) between treatments and water layers within lake sides were studied with nested two-way ANOVA with post hoc tests. Differences in the relative abundances of key bacterial taxa (Chlorobium, Burkholderiales, OD1, and Rhodospirillales) in the hypolimnion were examined with two-way ANOVA with post hoc tests, or with two-way adjusted ranks transformation test (ART; Leys and Schumann 2010). In the

\footnotetext{
${ }^{5}$ http://www.mothur.org/
} 
result, Basin refers to the different lake sides that are separated with the plastic curtain and Treatment refers to fish addition (meaning before and after fish addition). For inspecting bacterial community composition, functions from the Vegan package (Oksanen et al. 2013) were used. Nonmetric multidimensional scaling (NMDS, conducted with metaMDS function) plots calculated based on Morisita-Horn distance matrix (Horn 1966) were used to visualize dynamics in community structure ( $\beta$-diversity) of bacteria (OTUs represented by at least 50 reads) for total data as well as separately for the three water layers. Before NMDS, Wisconsin and square-root transformations were applied to OTU abundance data. Environmental data (oxygen concentration, temperature, DOC concentration, inorganic nitrogen concentrations $\left(\mathrm{NO}_{2}^{-}+\mathrm{NO}_{3}^{-} \mathrm{NH}_{4}^{+}\right)$, phosphate concentration $\left(\mathrm{PO}_{4}^{3-}\right)$ as well as Daphnia density and season were fitted to the ordination using the function "envfit." Differences in bacterial community between water layers as well as changes in the bacterial community within a water layer, between lake basins, and treatments (separately and their interactions) were tested with permutational multivariate analysis of variance (PERMANOVA) using the function "adonis" in R. To normalize the data, logtransformation was used for the inverse Simpson index and cube-root transformation for bacterial cell counts.

\section{RESULTS}

Mekkojärvi developed steep stratification every year from May to September, resulting in a shallow oxic epilimnion (maximum depth $0.5 \mathrm{~m}$ ) and anoxic meta- and hypolimnion (Appendix S1: Table S1). Average nutrient concentrations $\left(\mathrm{NH}_{4}^{+}, \mathrm{NO}_{3}^{-}+\mathrm{NO}_{2}^{-}\right.$and $\left.\mathrm{PO}_{4}^{3-}\right)$ were 10 -fold higher in the hypolimnion than in the epilimnion
(Table S1), but the concentrations did not differ between the two experimental lake basins in the epilimnion or in the hypolimnion (Mann-Whitney $U, P>0.05$ ). However, in the metalimnion $(0.5-1.0 \mathrm{~m}) \mathrm{NH}_{4}-\mathrm{N}$ and $\mathrm{PO}_{4}-\mathrm{P}$ concentrations were higher in the fish-absent basin than in the fish-present basin (Mann-Whitney $U, P=0.004$ and $P=0.004$, respectively; Table S1).

Prior to fish addition, oxygen concentrations were slightly higher in the epilimnion and metalimnion (MannWhitney $U, P=0.009$ and $P=0.03$, respectively) in the fish-present basin, whereas after fish addition no differences were observed (Mann-Whitney $U, P>0.05$ ). The bacterial cell counts from 2012 indicated that the fish addition and water depth were the most important factors affecting bacterial density (Fig. 1). Before fish addition, bacterial cell densities increased from epi- to hypolimnion in both basins. After fish addition, cell densities were higher in the fish-present than in the fishabsent basin in all depth layers. When comparing the situation before fish addition to that after fish addition within basins, cell-densities decreased in all depth layers in the fish-absent basin, whereas in the fish-present basin, they remained almost at the same level (Fig. 1). The observed difference in the cell densities was smaller in the epilimnion ( $28 \%$ difference) than in the metalimnion or hypolimnion (68\% difference in both). However, due to the low number of replicates $(n=2)$ no statistical analysis could be done with reliable results.

Number of observed OTUs at $97 \%$ similarity level varied between 244 and 910 within samples, and was on average 509, 566, and 603 in epi-, meta-, and hypolimnion samples, respectively. The bacterial community composition visualized with NMDS clearly differed between the different depth layers (Fig. 2), with epilimnion and

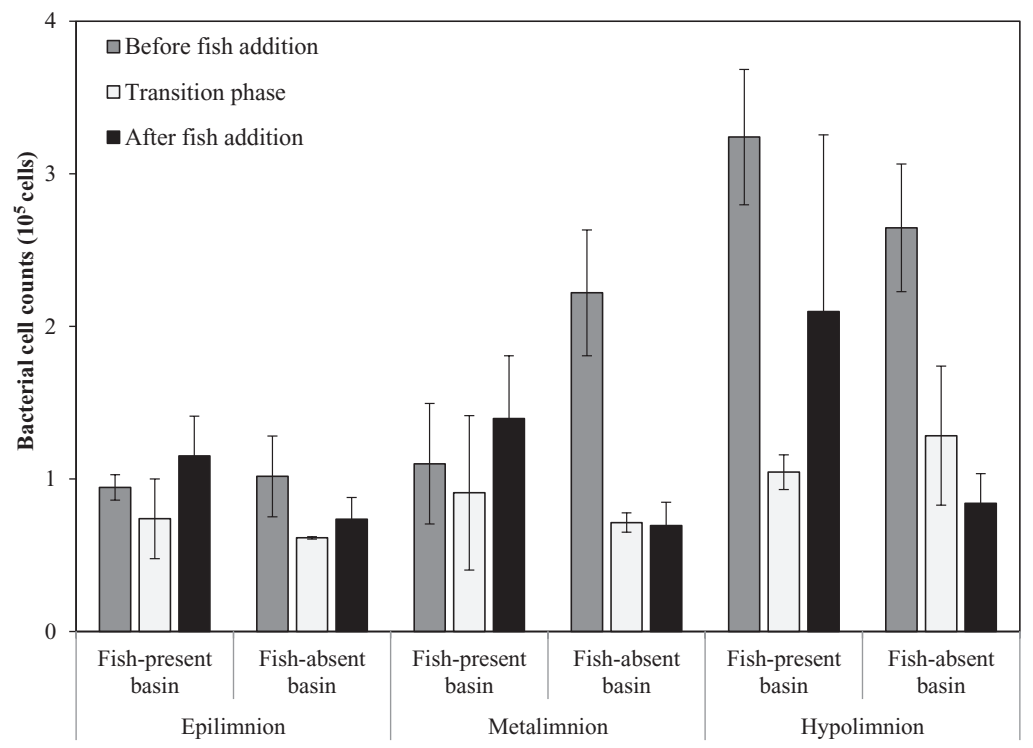

FIG. 1. Bacterial cell counts (mean \pm SE) from 2012 from different depth layers and lake basins before fish addition (three sampling times), after fish addition (two sampling times), and during the transition phase just after fish addition (two sampling times). 


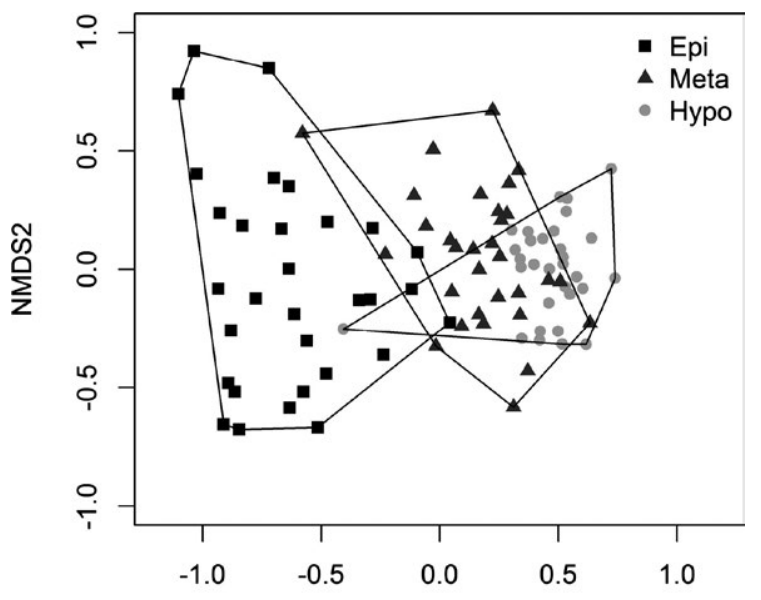

NMDS1

FIG. 2. Nonmetric multidimensional scaling plots of $16 \mathrm{~S}$ rRNA gene OTUs describing the bacterial community structure in the epilimnion (Epi, squares), metalimnion (Meta, triangles) and hypolimnion (Hypo, circles). Data cover sampling occasions throughout the entire three-year experiment (altogether 16 sampling occasions, 4 in 2011, 7 in 2012, and 5 in 2013, from all the three layers and both lake basins, $n=96$ ). Stress value is 15.83 .

hypolimnion being most separated and the metalimnetic communities intermediate. The inverse Simpson index, measuring diversity, was significantly lower in the metaand hypolimnion than in the epilimnion, when comparing the different water layers within each basin $(P<0.005)$. The hypolimnion exhibited a lower bacterial diversity, as one single OTU comprised on average $41 \%$ of the whole hypolimnetic community, while only 19 OTUs had relative abundance higher than $0.5 \%$ and their total number comprised $70 \%$ of the sequences (Fig. 3). The number of OTUs contributing more than $0.5 \%$ of the total community was greater in the epilimnion, where 30 OTUs contributed $60 \%$ of the total community, and in the metalimnion, where 27 OTUs contributed $68 \%$ of the total community.

The microbial community composition was affected by the treatment (i.e., fish presence/absence) and study year in all depth layers, while lake basin was found to shape community composition in the epilimnion and the hypolimnion (Table 1). Both Chao richness index and inverse Simpson index remained similar throughout the season regardless of fish addition (Table 2). Bacterial community richness (Chao) in the fish-present basin increased from the epilimnion to the hypolimnion $(P<0.001)$, but no difference in richness was seen between these layers in the fish-absent basin $(P>0.05$, Appendix S1: Table 2). The inverse Simpson index was lower in the fish-absent basin than in the fish-present basin $(P=0.024)$. Because the epilimnetic community compositions were found to be distinct between the two lake basins $(P=0.003)$, we evaluated separately which environmental factors had most influence on the communities. $\mathrm{NO}_{2}^{-}+\mathrm{NO}_{3}^{-}$concentrations correlated with the epilimnetic community composition in both basins, oxygen correlated with the community in the fish-present basin and DOC in the fish-absent basin (Fig. 4). The metalimnetic and hypolimnetic communities were controlled by the same environmental parameters and thus assessed together without basin distinction. Highest correlations were observed between oxygen concentration in the metalimnion, and temperature in the hypolimnion, and season in both depth layers (Fig. 4).

Four phylogenetic groups dominated the microbial community throughout the water column in all the study years (Appendix S2: Figs S1-S3). The most abundant OTU (OTU001) overall in the water column was assigned to the green sulfur bacteria (GSB) group, genus Chlorobium. This OTU contributed on average $8 \%, 36 \%$, and $41 \%$ of all sequences in the epi-, meta-, and hypolimnion, respectively (Fig. 4). Altogether, from the 597 OTUs that contained at least 50 reads, 64 OTUs were classified as Chlorobium,
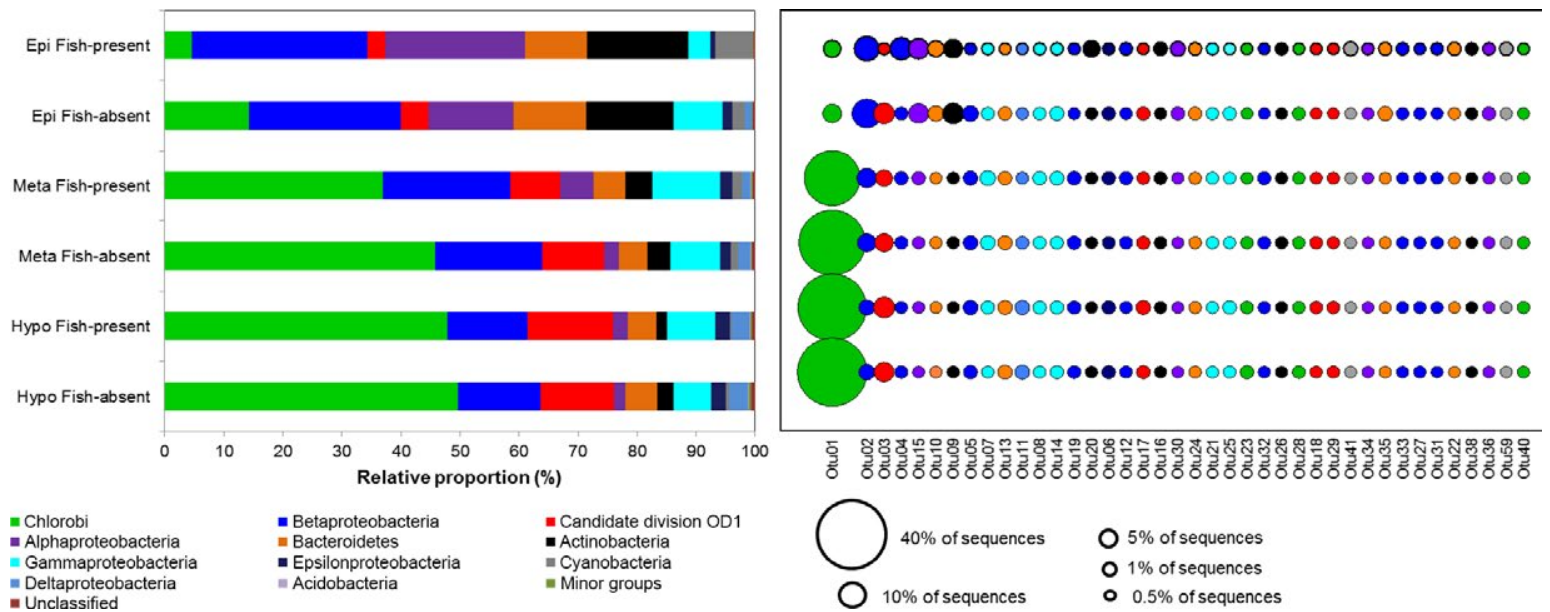

- Betaproteobacteria Bacteroidetes - Acidobacteria

- Candidate division $0 \mathrm{D} 1$ - Actinobacteria - Cyanobacteri
- $1 \%$ of sequences

- $0.5 \%$ of sequences

FIG. 3. Phylogenetic classification of the 40 most abundant 16S rRNA gene OTUs from the two lake basins and the three depth layers. Relative proportion of each OTU is shown by the circle size. 
TABLE 1. Results of permutational multivariate analysis of variance (PERMANOVA) comparing epilimnetic, metalimnetic, and hypolimnetic bacterial communities between treatments and basins, within each layer.

\begin{tabular}{|c|c|c|c|c|c|c|c|}
\hline \multirow[b]{2}{*}{ Factor } & \multirow[b]{2}{*}{$\mathrm{df}$} & \multicolumn{2}{|c|}{ Epilimnion } & \multicolumn{2}{|c|}{ Metalimnion } & \multicolumn{2}{|c|}{ Hypolimnion } \\
\hline & & Pseudo $F$ & $P$ & Pseudo $F$ & $P$ & Pseudo $F$ & $P$ \\
\hline Year & 1.19 & 5.049 & $<0.05$ & 2.560 & $<0.05$ & 3.836 & $<0.05$ \\
\hline Treatment & 2.19 & 2.836 & $<0.05$ & 1.902 & $<0.05$ & 1.423 & $<0.05$ \\
\hline Basin & 1.19 & 4.757 & $<0.05$ & 1.416 & $\mathrm{~ns}$ & 1.442 & $<0.05$ \\
\hline Year $\times$ treatment & 2.19 & 2.062 & $<0.05$ & 1.150 & ns & 1.220 & ns \\
\hline Year $\times$ basin & 1.19 & 1.094 & $\mathrm{~ns}$ & 0.967 & ns & 1.103 & ns \\
\hline Treatment $\times$ basin & 2.19 & 1.351 & ns & 1.119 & ns & 1.010 & ns \\
\hline Year $\times$ treatment $\times$ basin & 2.19 & 0.862 & ns & 1.024 & ns & 0.890 & ns \\
\hline
\end{tabular}

Note: Boldface type highlights significant differences; ns, not significant.

which means that from the hypolimnetic and metalimnetic communities almost half of all bacterial sequences were assigned to these anaerobic phototrophs (Fig. 4). In the epilimnion, the order Burkholderiales, belonging to a class Betaproteobacteria, was the most abundant bacterial group comprising, on average, $24 \%$ of epilimnetic bacterial sequences, being the closest match for 67 OTUs (including the second most abundant OTU, OTU002). Members of group candidate division OD1 were also abundant and found in high densities from the hypolimnion and metalimnion (Fig. 4), where OTU003 was the second- and third-most abundant OTU; $12 \%$ of all sequences in the hypolimnion and $9 \%$ of those in the metalimnion were assigned to this division. A biogeochemically important group, MOB, was present in high numbers in all water layers, being most abundant in the metalimnion where they comprised, on average, $9 \%$ of the microbial community. All the sequences of methanotrophs belonged to Gammaproteobacteria group Methylococcales, which formed the dominant group in the sequences of Gammaproteobacteria. Of the key microbial groups of the hypolimnion (Chlorobium, Burkholderiales, OD1, and Rhodospirillales), Burkholderiales and Rhodospirillales abundance stayed at the same relative abundance throughout the whole season in both basins, whereas the proportion of Chlorobium decreased, and OD1 increased toward autumn (Appendix S3: Fig. S4).

\section{DisCUSSION}

Consistent with our expectations, an altered trophic cascade was seen to manifest at the microbial level in the lake experiment; the number of bacterial cells was higher in all depth layers in the basin where Daphnia were removed by the fish, indicating that fish addition decreased Daphnia grazing on bacteria. Daphnia are also capable of migrating vertically in the water column despite strong oxygen stratification (Arvola et al. 1992), explaining why we found higher bacterial cell numbers throughout the water column in the fish-present basin. We found distinct microbial community structures and dominant OTUs in each water layer and in each study year. Fish addition was found to alter microbial community composition in the epilimnion and hypolimnion, where in addition the abiotic environmental factors exerted important controls on the community structures. Although differences in community composition were found between years, the same core phylogenetic groups dominated the microbial communities in each study year.

In accordance with our expectations, the effect of an altered trophic cascade was seen in the epilimnion, where microbial communities differed between fish-present and fish-absent basins. In addition, abiotic factors, such as nutrient and oxygen concentrations, were found to control the microbial community compositions. DOC concentration has been repeatedly linked to lake microbial communities in which Betaproteobacteria and Bacteroidetes, both abundant in our samples, have been shown to favor high DOC concentrations (Burkert et al. 2003, Eiler et al. 2003, Hutalle-Schmelzer et al. 2010). Nitrate concentration was connected to epilimnetic communities, and has also been shown to control the sediment community composition in freshwaters (Zhang et al. 2015) where it can further affect biogeochemical processes and greenhouse gas $\mathrm{N}_{2} \mathrm{O}$ production (PiñaOchoa and Álvarez-Conbelas 2006, Saarenheimo et al. 2015). In addition, the difference in microbial community composition between lake basins can be explained by different selection forces. In the fish-present basin, the top-down selection force (Daphnia) was removed enabling within-microbial-community interactions, such as competition. In the fish-absent basin, Daphnia were presumed to exert high unselective grazing pressure. However, we did not find any clear interactions between Daphnia density and the main key microbial groups, possibly because the dominant OTUs were insensitive to Daphnia grazing, masking changes in minor OTUs. In contrast to our expectations, removal of Daphnia also modified the hypolimnetic microbial community composition, which probably reflects the absence of vertically migrating Daphnia (Arvola et al. 1992, Taipale et al. $2009 a$ ). We suggest that the hypolimnetic microbial community in the fish-absent basin was modified by both Daphnia grazing and abiotic factors, which might have 

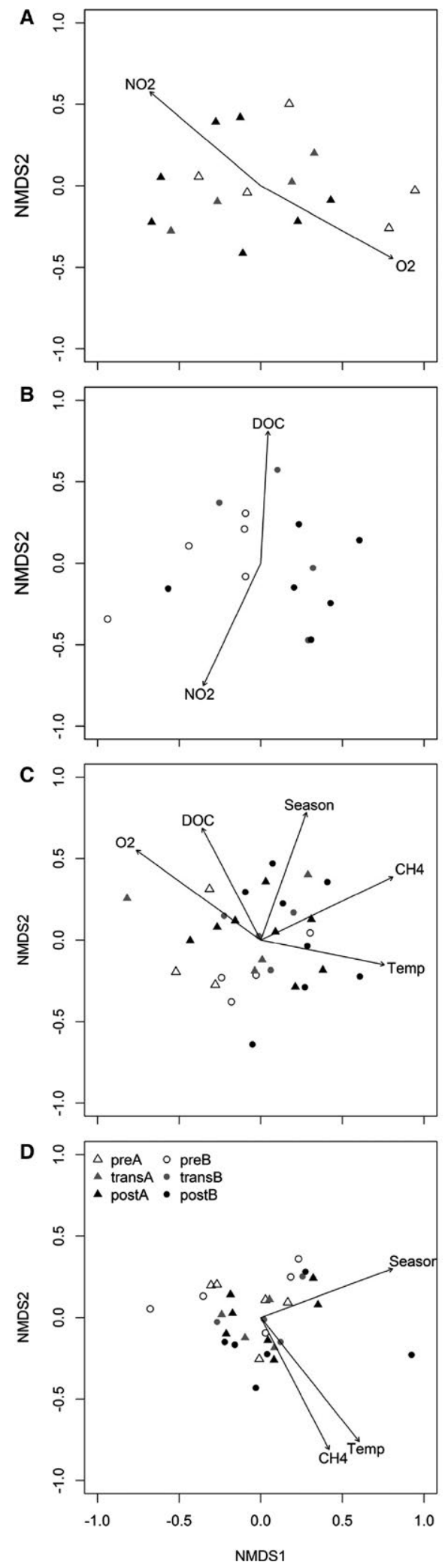

favored fast growing bacterial taxa. Furthermore, we suggest that only seasonal factors (e.g., temperature and oxygen) controlled the community in the fish-present
FIG. 4. Nonmetric multidimensional scaling (NMDS) plots of $16 \mathrm{~S}$ rRNA gene OTUs to visualize environmental factors controlling the $\beta$-diversity of (A) epilimnetic bacterial communities in the fish-present basin, (B) epilimnetic communities in the fish-absent basin, (C) metalimnetic communities from both basins combined, and (D) hypolimnetic communities from both basins combined. Treatment basins and treatment status are marked with triangles (A, fish-present basin) and circles (B, fishabsent basin), and with colors (white, before fish addition; grey, transition phase; and black, after fish addition). Abbreviations are DOC, dissolved organic carbon and Temp, temperature.

basin, leading to dominance of slow-growing bacterial groups. Similarly, the metalimnetic community was affected by seasonal factors in both basins.

Our results corroborate previous findings that anoxic waters of steeply stratified lakes harbor unique microbial communities (Shade et al. 2008, Peura et al. 2012a), which are not usually classified as belonging to the common freshwater tribes (Newton et al. 2011). We found that the anoxic water layers (metalimnion and hypolimnion) were overwhelmingly dominated by green sulfur bacteria (Chlorobium), which are obligate anaerobic photoautotrophs and thus an important but largely unacknowledged part of the carbon cycle (Van Gemerden and Mas 1995, Karhunen et al. 2013). In addition, the bacterial group belonging to candidate division OD1 was found to be abundant. The role of OD1 in lake ecosystems is currently unknown. We found OD1 continuously throughout the open water seasons from both metalimnion and hypolimnion in relative abundances similar to those earlier reported from Mekkojärvi and other nearby lakes (Peura et al. 2012a). We could also see that the proportion of OD1 increased in both lake basins toward autumn in the hypolimnion. The relative proportion of OD1 might even have been underestimated due to the primer choice (Peura et al. 2012a). In contrast, a few epilimnetic samples might have contained some OTUs from the metalimnion, as strictly anaerobic GSB and presumably anoxic OD1 were recorded from those epilimnetic samples; this probably means that the bottom of our 60-cm Limnos sampler may have sometimes penetrated below the extremely narrow oxic epilimnion in the lake.

Spring and autumn mixing events have been shown to modify the microbial communities of small humic lakes by destroying the conditions necessary for strictly anaerobic groups and supporting the growth of minor groups (Taipale et al. 2011, Garcia et al. 2013). Although communities were found to differ between years, the same dominant phylogenetic groups developed repeatedly in each study year in the two lake basins after the possible spring mixing. The community compositions of the lower water layers were clearly affected by the seasonal succession, as reported previously (Shade et al. 2007, Crump et al. 2009, Eiler et al. 2012). Thus it seems that abiotic factors are more significant in controlling the microbial community than biotic factors (e.g., Daphnia) in this kind of sheltered boreal lake. One reason for this could be that Daphnia removal opened a feeding niche for other 
TABLE 2. Impact of treatment, basin, and layer within basin on Chao index and Inverse Simpson index, and pairwise comparisons between layers within basins (nested two-way ANOVA with post hoc tests).

\begin{tabular}{|c|c|c|c|c|c|}
\hline \multirow[b]{2}{*}{ Factor } & \multirow[b]{2}{*}{ df } & \multicolumn{2}{|c|}{ Chao index } & \multicolumn{2}{|c|}{ Inverse Simpson index } \\
\hline & & $F$ & $P$ & $F$ & $P$ \\
\hline Treatment & 2.75 & 1.255 & ns & 1.901 & ns \\
\hline Basin & 1.75 & 1.587 & ns & 5.304 & 0.024 \\
\hline Basin (layer) & 4.75 & 10.843 & $<0.001$ & 22.125 & $<0.001$ \\
\hline Treatment $\times$ basin (layer) & 10.17 & 1.055 & ns & 1.940 & ns \\
\hline Layer (basin fish-present) & & & $<0.001$ & & $<0.001$ \\
\hline Layer (basin fish-absent) & & & ns & & $<0.001$ \\
\hline Epi-meta (fish-present) & & & $<0.001$ & & 0.005 \\
\hline Epi-hypo (fish-present) & & & $<0.001$ & & $<0.001$ \\
\hline Meta-hypo (fish-present) & & & 0.028 & & ns \\
\hline Epi-meta (fish-absent) & & & ns & & $<0.001$ \\
\hline Epi-hypo (fish-absent) & & & ns & & $<0.001$ \\
\hline Meta-hypo (fish-absent) & & & ns & & ns \\
\hline
\end{tabular}

Notes: Abbreviations are epi, epilimnion; meta, metalimnion; hypo, hypolimnion. Boldface values highlight significant differences; ns, not significant.

bacterivores, such as rotifers and ciliates (Järvinen and Salonen 1998, Jürgens et al. 1999, Zöllner et al. 2003), which could then have exerted similar grazing pressure and top-down control towards the microbial communities as Daphnia had before fish addition. In particular, top-down grazing pressure by ciliate and flagellate protists on bacteria has been shown to modify both the size fractionation and structure of microbial communities (Pernthaler 2005), where especially Alphaproteobacteria, Actionobacteria, and Flavobacterium have been shown to develop grazing-resistant forms and become the most abundant bacterial groups (Jürgens et al. 1999, Pernthaler 2005). We do not have quantitative information about the abundance of rotifers or ciliates during the experiment. However, while counting crustacean zooplankton, rotifers were observed only in low numbers throughout the ice free season and within each treatment basin, and the altered trophic cascade was not seen to induce any noticeable change in the abundance of rotifers. Regarding ciliates, the minor decrease in bacterial cell densities in the epilimnion but not in the hypolimnion in the fishabsent basin in 2012 could reflect a greater presence of ciliates in the epilimnion, but their densities must have been low because there was still an observable difference between lake basins. Hence, although the removal of Daphnia by the introduced fish may have been partly compensated by greater development of other bacterivorous zooplankton groups, the responses seen in the microbial community composition and abundance suggest that any such compensation remained limited.

In conclusion, the microbial community composition was affected partly by the top-down tri-trophic cascade, but more strongly by natural abiotic factors, which were linked to the season and other abiotic characteristics of the lake. The steep stratification patterns with low $\mathrm{pH}$, low oxygen concentrations, and restricted light intensities in lower water layers created an extreme environment in the deeper layers where only certain specialized groups were able to grow. However, there was an effect of tri-trophic cascades on bacterial abundance, as cell numbers were higher in the fish-present than in the fish-absent basin. This finding is further supported by previous results where quantitative abundance of MOBs was assessed throughout the entire three-year experiment, and similar responses in the bacterial cell numbers were observed (Devlin et al. 2015). The effect of the altered trophic cascade could even be further connected to lake biogeochemical processes as reduced methane emissions were measured from the fish-present basin (Devlin et al. 2015). It seems that in the future, when climate change and anthropogenic activities are expected to modify characteristics in aquatic ecosystems (reviewed in Jeppesen et al. 2009), microbial abundance and community composition may be modified not only directly by changing nutrient inputs or oxygen concentrations, but also by altered trophic cascades. Furthermore, changes in microbial community composition might lead to changes in biogeochemical cycles and in greenhouse gas emissions (Thakur et al. 2014, Devlin et al. 2015).

\section{ACKNOWLEDGMENTS}

We thank Lammi Biological Station, University of Helsinki, for providing facilities. J. Vesterinen helped in the field and with zooplankton calculations. We are also grateful for the expertise and assistance of M. Rask and S. Vesala from the Finnish Game and Fisheries Research Institute. The project was funded by Academy of Finland grant 137671 to R. I. Jones and grant 260797 to M. Tiirola, and by EnSTe Graduate School grant to J. Saarenheimo.

\section{Literature Cited}

Arvola, L., K. Salonen, P. Kankaala, and A. Lehtovaara. 1992. Vertical distributions of bacteria and algae in a steeply 
stratified humic lake under high grazing pressure from Daphnia longispina. Hydrobiologia 229:253-269.

Burkert, U., F. Warnecke, D. Babenzien, E. Zwirnmann, and J. Pernthaler. 2003. Members of a readily enriched $\beta$-proteobacterial clade are common in surface waters of a humic lake. Applied and Environmental Microbiology 69:6550-6559.

Crump, B. C., B. J. Peterson, P. A. Raymond, R. M. W. Amon, A. Rinehart, J. W. McCelland, and R. M. Holmes. 2009. Circumpolar synchrony in big river bacterioplankton. Proceedings of the National Academy of Science USA 106:21208-21212.

de Vries, F. T., and A. Shade. 2013. Controls on soil microbial stability under climate change. Frontiers in Microbiology 4:265.

Devlin, S. P., J. Saarenheimo, J. Syväranta, and R. I. Jones. 2015. Top consumer abundance influences lake methane efflux. Nature Communications 6. doi:10.1038/ncomms9787.

Eiler, A., S. Langenheder, S. Bertilsson, and L. J. Tranvik. 2003. Heterotrophic bacterial growth efficiency and community structure at different natural organic carbon concentrations. Applied and Environmental Microbiology 69:3701-3709.

Eiler, A., F. Heinrich, and S. Bertilsson. 2012. Coherent dynamics and association networks among lake bacterioplankton taxa. ISME Journal 6:330-342.

Garcia, L. S., I. Saika, H.-P. Grossart, and F. Warnecke. 2013. Depth-discrete profiles of bacterial communities reveal pronounced spatio-temporal dynamics to lake stratification. Environmental Microbiology Reports 5:549-555.

Gasol, J. M., C. Pedros-Alio, and D. Vaque. 2002. Regulation of bacterial assemblages in oligotrophic plankton systems: results from experimental and empirical approaches. Antonie van Leeuwenhoek 81:435-452.

Grossart, H. P., J. Jezbera, K. Horňák, K. M. L. Hutalle, U. Buck, and K. Šimek. 2008. Top-down and bottom-up induced shifts in bacterial abundance, production and community composition in an experimentally divided humic lake. Environmental Microbiology 10:635-652.

Haukka, K., E. Heikkinen, T. Kairesalo, H. Karjalainen, and K. Sivonen. 2005. Effect of humic material on the bacterioplankton community composition in boreal lakes and mesocosms. Environmental Microbiology 7:620-630.

Hutalle-Schmelzer, K. M. L., E. Zwirnmann, A. Krüger, and H. P. Grossart. 2010. Enrichment and cultivation of pelagic bacteria from a humic lake using phenol and humic matter additions. FEMS Microbiology Ecology 72:58-73.

Jansson, M., A.-K. Bergström, P. Blomqvist, and S. Drakare. 2000. Allochthonous organic carbon and phytoplankton/ bacterioplankton production relationships in lakes. Ecology 81:3250-3255.

Järvinen, M., and K. Salonen. 1998. Influence of changing food web structure on nutrient limitation of phytoplankton in a highly humic lake. Canadian Journal of Fisheries and Aquatic Sciences 55:2562-2571.

Jeppesen, E., B. Kronvang, M. Meerhoff, J. Søndergaard, K. M. Hansen, H. E. Andersen, T. L. Lauridsen, M. Beklioglu, A. Özen, and D. J. Lipman. 2009. Climate change effects on runoff, catchment phosphorus loading and lake ecological state, and potential adaptations. Journal of Environmental Quality 38:1930-1941.

Jones, R. I. 1992. The influence of humic substances on lacustrine planktonic food chains. Hydrobiologia 229:73-91.

Jürgens, K., H. Arndt, and H. Zimmermann. 1997. Impact of metazoan and protozoan grazers on bacterial biomass distribution in microcosm experiments. Aquatic Microbial Ecology 12:131-138

Jürgens, K., J. Pernthaler, S. Schalla, and R. Amann. 1999. Morphological and compositional changes in a planktonic bacterial community in response to enhanced protozoan grazing. Applied and Environmental Microbiology 65:1241-1250.

Kankaala, P., J. Huotari, E. Peltomaa, T. Saloranta, and A. Ojala. 2006. Methanotrophic activity in relation to methane efflux and total heterotrophic bacterial production in a stratified, humic, boreal lake. Limnology and Oceanography 51:1195-1204.

Karhunen, J., L. Arvola, S. Peura, and M. Tiirola. 2013. Green sulphur bacteria as a component of the photosynthetic plankton community in small dimictic humic lakes with an anoxic hypolimnion. Aquatic Microbial Ecology 68:267-272.

Kent, A. D., S. E. Jones, A. C. Yannarell, J. M. Graham, G. H. Lauster, T. K. Kratz, and E. W. Triplett. 2004. Annual patterns in bacterioplankton community variability in a humic lake. Microbial Ecology 48:550-560.

Leys, C., and S. Schumann. 2010. A nonparametric method to analyze interactions: the adjusted rank transform test. Journal of Experimental Social Psychology 46:684-688.

Lindström, E. S. 2000. Bacterioplankton community composition in five lakes differing in trophic status and humic content. Microbial Ecology 40:104-113.

Lindström, E. S., and E. Leskinen. 2002. Do neighbouring lakes share common taxa of bacterioplankton? Comparison of $16 \mathrm{~S}$ rDNA fingerprints and sequences from three geographic regions. Microbial Ecology 44:1-9.

Lindström, E. S., M. P. Kamst-Van Agterveld, and G. Zeart. 2005. Distribution of typical freshwater bacterial groups is associated with $\mathrm{pH}$, temperature, and lake water retention time. Applied and Environmental Microbiology 71:8201-8206.

Muylaert, K., K. Van der Gucht, N. Vloemans, L. De Meester, M. Gillis, and W. Vyverman. 2002. Relationship between bacterial community composition and bottom-up versus topdown variables in four eutrophic shallow lakes. Applied and Environmental Microbiology 68:4740-4750.

Newton, R. J., S. E. Jones, A. Eiler, K. D. McMahon, and S. Bertilsson. 2011. A guide to the natural history of freshwater lake bacteria. Microbiology and Molecular Biology Reviews 75:14-49.

Oksanen, J., et al. 2013. vegan: Community Ecology Package. $\mathrm{R}$ Package Version 2.0-10. http://CRAN.R-project.org/ package $=$ vegan .

Pernthaler, J. 2005. Predation on prokaryotes in the water column and its ecological implications. Nature Reviews Microbiology 3:537-546.

Peura, S., A. Eiler, S. Bertilsson, H. Nykänen, M. Tiirola, and R. I. Jones. 2012a. Distinct and diverse anaerobic bacterial communities in boreal lakes dominated by candidate division OD1. ISME Journal 6:1640-1652.

Peura, S., A. Eiler, M. Hiltunen, H. Nykänen, M. Tiirola, and R. I. Jones. 2012 b. Bacterial and phytoplankton responses to nutrient amendments in a boreal lake differ according to season and to taxonomic resolution. PLoS ONE 7:e38552.

Peura, S., H. Nykänen, P. Kankaala, A. Eiler, M. Tiirola, and R. I. Jones. 2013. Enhanced greenhouse gas emissions and changes in plankton communities following an experimental increase in organic carbon loading to a humic lake. Biogeochemistry 118:177-194.

Piña-Ochoa, E., and M. Álvarez-Conbelas. 2006. Denitrification in aquatic environments: a cross-system analysis. Biogeochemistry 81:111-130.

Pruesse, E., C. Quast, K. Knittel, B. Fuchs, W. Ludwig, J. Peplies, and F. O. Glöckner. 2007. SILVA: a comprehensive online resource for quality checked and aligned ribosomal 
RNA sequence data compatible with ARB. Nucleic Acids Research 35:7188-7196.

Pruesse, E., J. Peplies, and F. O. Glöckner. 2012. SINA: accurate high-throughput multiple sequence alignment of ribosomal RNA genes. Bioinformatics 28:1823-1829.

R Core Team 2014. R: A language and environment for statistical computing. R Foundation for Statistical Computing, Vienna, Austria. http://www.R-project.org/.

Rahkola, M., J. Karjalainen, and V. Avinsky. 1998. Individual weight estimates of zooplankton based on length-weight regressions in Lake Ladoga and Saimaa Lake system. Nordic Journal of Freshwater Research 74:100-111.

Saarenheimo, J., A. J. Rissanen, L. Arvola, H. Nykänen, M. F. Lehmann, and M. Tiirola. 2015. Genetic and environmental controls on nitrous oxide accumulation in lakes. PLoS ONE 103:e0121201.

Salonen, K., and A. Lehtovaara. 1992. Migrations of hemoglobin-rich daphnia-longispina in a small, steeply stratified, humic lake with an anoxic hypolimnion. Hydrobiologia 229:271-288.

Schloss, P. D., S. L. Westcott, T. Ryabin, et al. 2009. Introducing mothur: open-source, platform-independent, communitysupported software for describing and comparing microbial communities. Applied and Environmental Microbiology 75:7537-7541.

Shade, A., A. D. Kent, R. J. Newton, S. E. Jones, E. W. Triplett, and K. D. McMahon. 2007. Interannual dynamics and phenology of bacterial communities in a eutrophic lake. Limnology and Oceanography 52:487-494.

Shade, A., S. E. Jones, and K. McMahon. 2008. The influence of habitat heterogeneity on freshwater bacterial community composition and dynamics. Environmental Microbiology 10:1057-1067.

Taipale, S., P. Kankaala, M. Tiirola, and R. I. Jones. 2008. Whole-lake DI13C additions reveal seasonal shifts between multiple food source contributions to zooplankton diet. Ecology 89:463-474.

Taipale, S., R. I. Jones, and M. Tiirola. 2009a. Vertical diversity of bacteria in an oxygen-stratified humic lake, evaluated using DNA and phospholipid analyses. Aquatic Microbial Ecology 55:1-16.
Taipale, S., P. Kankaala, H. Hämäläinen, and R. I. Jones. $2009 \mathrm{~b}$. Seasonal shifts in the diet of lake zooplankton revealed by phospholipid fatty acid analysis. Freshwater Biology 54:90-104.

Taipale, S., P. Kankaala, M. W. Hahn, R. I. Jones, and M. Tiirola. 2011. Methane oxidizing and photoautotrophic bacteria are significant producers in an oxygen-stratified humic lake. Aquatic Microbial Ecology 64:81-95.

Thakur, M. P., J. W. van Groenigen, I. Kuiper, and G. B. De Deyn. 2014. Interactions between microbial-feeding and predatory soil fauna trigger $\mathrm{N}_{2} \mathrm{O}$ emissions. Soil Biology and Biochemistry 70:256-262.

Tranvik, L. J. 1992. Allochthonous dissolved organic matter as an energy source for pelagic bacteria and the concept of the microbial loop. Hydrobiologia 229:107-114.

Van Gemerden, H., and J. Mas. 1995. Ecology of phototrophic sulfur bacteria. Pages 49-85 in R. E. Blankenship, M. T. Madigan and C. E. Bauer, editors. Anoxygenic photosynthetic bacteria. Springer Science \& Business Media, New York, New York, USA.

Yannarell, A. C., and E. W. Triplett. 2005. Geographic and environmental sources of variation in lake bacterial community composition. Applied Environmental Microbiology 71:227-239.

Zeng, J., L. Y. Yang, J. Y. Li, Y. Liang, L. Xiao, L. J. Jiang, and D. Y. Zhao. 2009. Vertical distribution of bacterial community structure in the sediments of two eutrophic lakes revealed by denaturing gradient gel electrophoresis (DGGE) and multivariate analysis techniques. World Journal of Microbiology and Biotechnology 25:225-233.

Zhang, J., Y. Yang, L. Zhao, Y. Li, S. Xie, and Y. Liu. 2015. Distribution of sediment bacterial and archaeal communities in plateau freshwater lakes. Applied Microbiological Biotechnology 99:3291-3302.

Zöllner, E., B. Santer, M. Boersma, H.-G. Hoppe, and K. Jürgens. 2003. Cascading predation effects of Daphnia and copepods on microbial food web components. Freshwater Biology 48:2174-2193.

Zubkov, M. V., and P. H. Burkill. 2006. Syringe pumped high speed flow cytometry of oceanic phytoplankton. Cytometry A 69A:1010-1019.

\section{SUPPORTING INFORMATION}

Additional supporting information may be found in the online version of this article at http://onlinelibrary.wiley.com/ doi/10.1890/15-1052.1/suppinfo 